\title{
The effect of surface texture on the retention of single implant-supported crowns cemented on wide-platform abutments
}

Open Access

\author{
Luis Gustavo Rabello Drummond ${ }^{a}$, Regenio Mahfuz Herbstrih Segundo ${ }^{\mathrm{b}}$, Hugo Mitsuo Silva Oshima ${ }^{\mathrm{b}}$, \\ Rosemary Sadami Arai Shinkai ${ }^{\text {b }}$
}

\begin{abstract}
OBJECTIVE: This in vitro study evaluated the retention of copings cemented with a provisional cement and a permanent cement on wide-platform short abutments with different surface texture. METHODS: Two wide-platform abutments (height $4.0 \mathrm{~mm}$ ) with machined (original) or modified surface (air-blasted with $50-\mu \mathrm{m}$ aluminum oxide) were connected to two implant replicas under torque of $35 \mathrm{~N} . \mathrm{cm}$. Ten copings were cast in $\mathrm{Cr}$-Co alloy from calcinable cylinders. Each coping was luted on the abutment under an axial force of $5 \mathrm{~kg}$ for $10 \mathrm{~min}$, and the specimen was stored in a humid environment at $37^{\circ} \mathrm{C}$ for $20 \mathrm{~h}$. After mechanical cycling simulating masticatory fatigue for 7 days $\left(5754\right.$ cycles, 60 cycles $/ \mathrm{min}, 200 \mathrm{~N}, 37^{\circ} \mathrm{C}$ ), the specimens were subjected to a uniaxial tensile test at $0.5 \mathrm{~cm} / \mathrm{min}$, and the maximum retention strength $(\mathrm{N})$ was recorded. After testing, the surfaces were cleaned, and the procedures were repeated for each coping in the experimental group. Data were analyzed by Student $t$ test for paired samples.

RESULTS: For the temporary cement, the mean retention (SD) was 36.1 (10.7) $\mathrm{N}$ for the machined surface and $49.6(2.7) \mathrm{N}$ for the blasted surface $(\mathrm{P}=0.004)$ (37\% increase). For the zinc phosphate cement, the values were 292.0 (89.8) $\mathrm{N}$ and 440.6 (48.1) N, ( $<<0.001)$ (42\% increase).

CONCLUSION: The results suggest that the air-blasting of short and wide abutments increases the retention of the cast coping cemented with temporary or permanent cement.
\end{abstract}

Keywords: dental implants; cementation; retention; abutments.

\section{Efeito da textura superficial na retenção de coroas implanto-suportadas unitárias cimentadas sobre pilares largos}

\section{RESUMO}

OBJETIVO: Este estudo in vitro avaliou a retenção de coroas unitárias cimentadas com cimento provisório ou definitivo sobre pilares curtos e largos, em função da textura de superfície.

MÉTODOS: Dois pilares do tipo sólido e largo (altura 4,0 mm) com superfície lisa (original) e jateada com óxido de alumínio (50 micrômetros) foram conectados a duas réplicas de implante sob torque de $35 \mathrm{~N} . \mathrm{cm}$. A partir de cilindros calcináveis foram fundidos 10 copings metálicos em liga de cobalto-cromo. Cada coping foi cimentado sobre o pilar sob uma força axial de $5 \mathrm{~kg}$ por $10 \mathrm{~min}$, e o espécime foi armazenado em ambiente úmido a $37^{\circ} \mathrm{C}$ por 20 h. Após ciclagem mecânica simulando fadiga mastigatória por 7 dias ( 5754 ciclos, 60 ciclos/min, $200 \mathrm{~N}$, $37^{\circ} \mathrm{C}$ ), os espécimes foram submetidos ao teste de tração em máquina de ensaios universal a $0,5 \mathrm{~cm} / \mathrm{min}$ e a força máxima de retenção $(\mathrm{N})$ foi registrada. Após o teste, as superfícies foram limpas e os procedimentos foram repetidos para cada coping do grupo experimental. Os dados foram analisados por teste t de Student para amostras pareadas.

RESULTADOS: Para o cimento temporário, a retenção média (DP) foi de $36,1(10,7) \mathrm{N}$ para a superfície lisa e de $49,6(2,7) \mathrm{N}$ para a superfície jateada $(\mathrm{P}=0,004)(37 \%$ de aumento). Para o cimento de fosfato de zinco, as médias foram de $292,0(89,8) \mathrm{N}$ e 440,6 $(48,1) \mathrm{N},(\mathrm{P}<0,001)(42 \%$ de aumento).

CONCLUSÃO: Os resultados sugerem que o jateamento da superfície de pilares curtos e largos melhora a retenção do coping fundido cimentado tanto com cimento provisório quanto com cimento definitivo.

Palavras-chave: implantes dentários; cimentação; retenção; pilares.
aSc in Prosthodontics, School of Dentistry, Pontifical Catholic University of Rio Grande do Sul, Porto Alegre, RS, Brazil

${ }^{b}$ Professor, Department of Prosthodontics, School of Dentistry, Pontifical Catholic University of Rio Grande do Sul, Porto Alegre, RS, Brazil

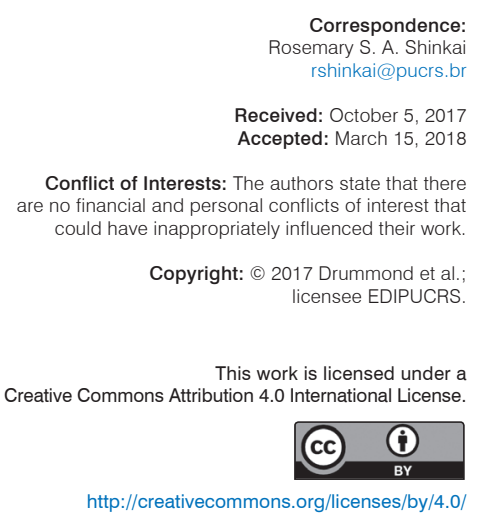

http://creativecommons.org/licenses/by/4.0/ 


\section{INTRODUCTION}

Cement-retained single crowns, splinted crowns, and cantilever-fixed partial dentures seem to perform better than screw-retained restorations in the long term [1]. Many factors related to the abutment (degree of taper, surface area, height, surface roughness), the crown (inner surface, properties of metal alloy) and the luting agent (type, composition, thickness) can affect the retention of cemented restorations $[2,3]$. The height and width of the abutment are geometric factors to determine the surface area to be luted, which are potentially related to the retention of crowns. A decrease in the taper degree of the abutment seem to increase more the retention strength of implant-supported crowns than the increase in height of the abutment $[4,5]$. However, sometimes it is difficult to optimize the taper degree of prefabricated abutments, the height and width of the abutment due to anatomical limitations. Furthermore, in some clinical situations, such as multi-unit angled abutments for fixed prostheses, an increase of taper degree may be necessary to allow a proper axis of insertion of the partial or full-arch restoration.

The modification of the abutment surface may increase the retention of the cemented coping, which could prevent frequent and undesirable decementation. A simple procedure to change the resistance of cemented crowns is changing the texture of the abutment surface. For example, the air-blasting with abrasive particles of aluminum oxide, use of diamond drills or grooves may increase the strength retention of the restoration cemented on abutment surfaces [6,7]. Thus, the surface texturing may be especially beneficial in cases of abutments with geometric challenging characteristics for mechanical retention, such as reduced height or tapered walls.

Regarding the type of cement, the temporary cement is often used for provisional restorations and semi-permanent cementation of final restorations, whereas the permanent cement has higher strength and lower solubility. For instance, the zinc phosphate cement can be used for cementing fixed prostheses where retrievability or provisionalization is not of primary concern, while the non-eugenol zinc oxide can be used in cases where decementation may be necessary for clinical maintenance overtime. The advantages of provisional cementation include the possibility of repair of fractures or damage to implant components, changes in the denture after implant loss, and surgical intervention [8]. However, the mechanical properties of temporary cements are lower than those of the permanent luting agents, which affects the retention strength of cemented restorations [9]. Thus, the change in the surface texture of the abutments may increase the retention of the restoration, avoiding frequent and undesired decementation.

The aim of this laboratory study was to evaluate the retention strength of metallic copings cemented on short and wide-platform abutments as a function of surface texture (machined vs. air-blasted with aluminum oxide) and type of cement (temporary vs. permanent).

\section{METHODS}

Two WN Solid abutments $6^{\circ}$ (Straumann, Basel, Switzerland), with angulation $6^{\circ}$, height $4.0 \mathrm{~mm}$, wide neck, and made of titanium were used: one original abutment (machined surface) and one abutment treated with surface air-blasting with aluminum oxide (A12O3). The air-blasting was carried out with particles of $\mathrm{Al} 2 \mathrm{O} 3$ with granulation of $50 \mu \mathrm{m}$, at a distance of $1 \mathrm{~cm}$, for 1 minute, under pressure of $90 \mathrm{kgf} / \mathrm{cm}^{2}$.

Two replicas of WN synOcta ${ }^{\circledR}$ implant (Straumann, Basel, Switzerland) was embedded axially in self-polymerizing acrylic resin using a circular matrix. The abutments were fixed on the implant replicas and torqued at $35 \mathrm{Ncm}$. Using calcinable cylinders on the abutments, ten copings were waxed-up with wax loops in the occlusal portion to allow the execution of the retention test [10]. The copings were cast with cobalt-chromo alloy according to laboratory standard procedures (Figure 1).

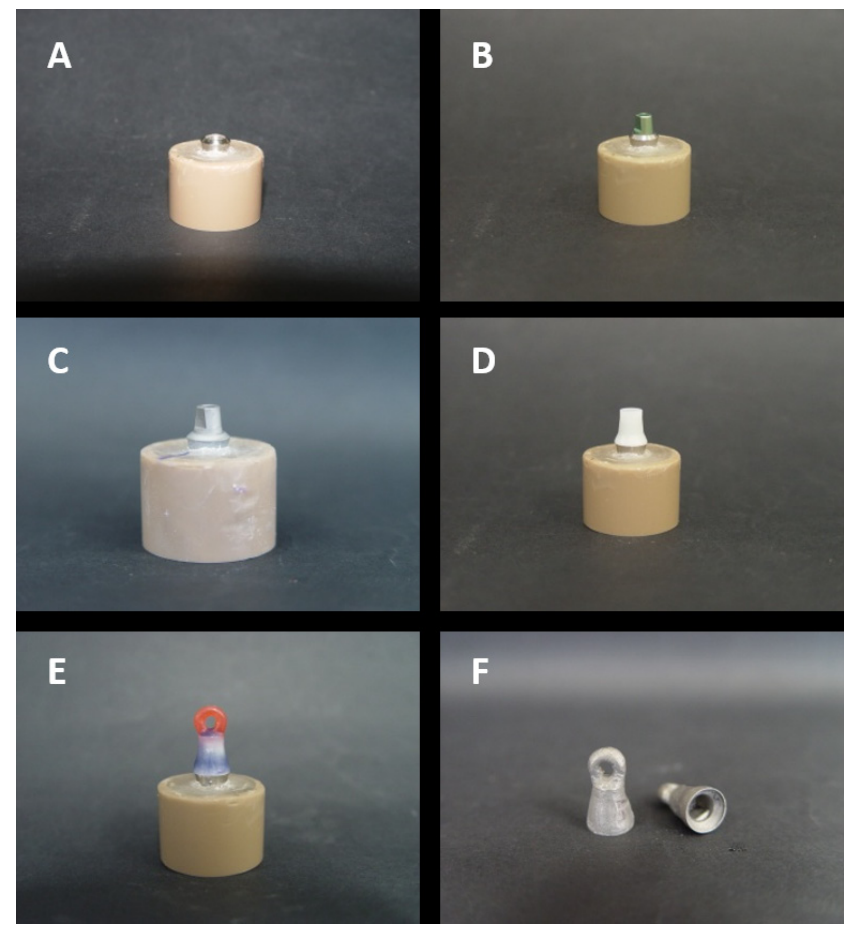

Figure 1. Specimen fabrication. Two replicas of WN synOcta ${ }^{\circledR}$ implant (Straumann, Basel, Switzerland) was embedded axially in self-polymerizing acrylic resin using a circular matrix (A). Two wideplatform abutments (height $4.0 \mathrm{~mm}$ ) with machined (original) (B) or modified surface (air-blasted with $50-\mu \mathrm{m}$ aluminum oxide) (C) were connected to two implant replicas under torque of $35 \mathrm{Ncm}$. Using calcinable cylinders on the abutments (D), ten copings were waxedup with wax loops in the occlusal portion (E) Ten copings were cast in Cr-Co alloy (F).

Two luting agents, a temporary non-eugenol zinc oxide cement (Temp Bond NE ${ }^{\circledR}$, Kerr / SybronEndo, Orange, CA, USA) and a permanent zinc phosphate cement (Fosfato de Zinco ${ }^{\circledR}$, SS White, Rio de Janeiro, Brazil), were tested for 
each type of abutment surface (machined vs. air-blasted), yielding four experimental groups. The cements were handled according to the manufacturers's specifications, and a portion of $0.1 \mathrm{~mL}$ was measured using an insuline syringe [9] to cement the coping on the abutment [3]. Before cementation, dental wax was placed on the abutment to cover the screw.

Each metallic coping was luted on the abutment under an axial force of $5 \mathrm{~kg}$ for $10 \mathrm{~min}$ [11] (Figure 2), and the specimen was stored in a humid environment at $37^{\circ} \mathrm{C}$ for $20 \mathrm{~h}$. The specimens were aged in a mechanical fatigue equipment (ER-11000, Erios, São Paulo, Brazil), where 5754 cycles were performed with load of $200 \mathrm{~N}$, at $37^{\circ} \mathrm{C}$, simulating masticatory efforts for seven days [12]. The specimens were subjected to a uniaxial tensile strength test using a universal testing machine (EMIC DL, São Jose dos Pinhais, PR, Brazil) at a speed of $0.5 \mathrm{~cm} / \mathrm{min}^{4}$ with a load cell of maximum force $1000 \mathrm{~N}$ [9]. The maximum retention strength was recorded as the peak strength of uniaxial tension (in Newtons) required to dislodge the coping from the abutment.

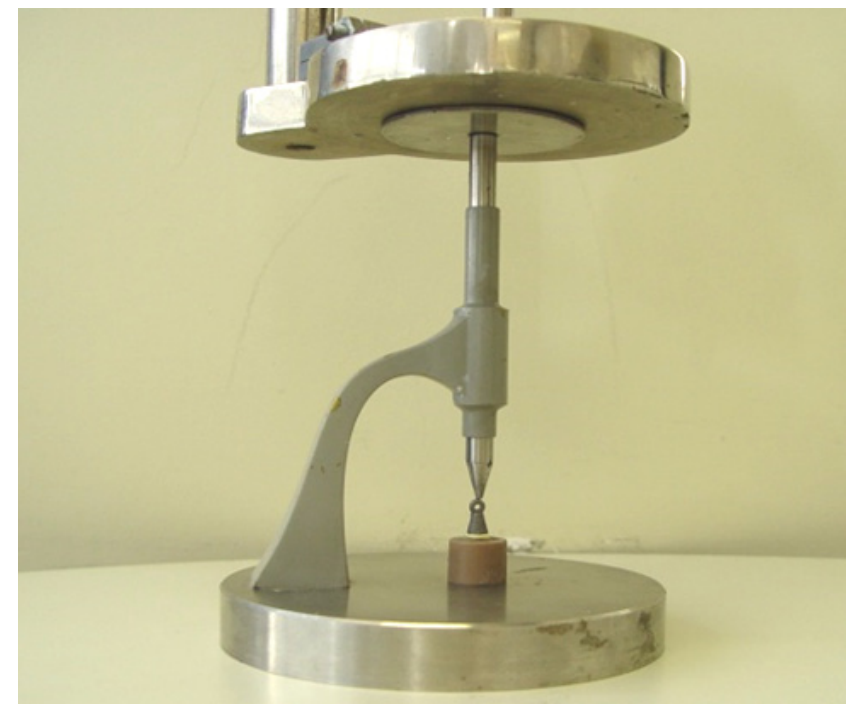

Figure 2. Specimen fabrication. Each metallic coping was luted on the abutment under an axial force of $5 \mathrm{~kg}$ for $10 \mathrm{~min}$.

After testing, the luted surfaces were cleaned by using manual curettes, ultrasound equipment, and chemical solution (benzene and ethyl alcohol). After removal of any residual cement debris, the surfaces were rinsed in running water, blasted with water steam, then dried with air blast. The modified-surface abutment was again blasted with aluminum oxide particles before each cementation procedure to restore the experimental surface treatment. The steps for cementing and mechanical testing were repeated for each coping in the four tested groups.

Data were statistically analyzed by Student t-test for paired samples, at the significance level of 0.05 .

\section{RESULTS}

For the temporary non-eugenol zinc oxide cement, the average maximum retention strength (SD) was $36.1(10.7) \mathrm{N}$ for the machined abutments and 49.6 (2.7) $\mathrm{N}$ for the modified surface abutments $(\mathrm{P}=0.004)$ (increase of 37\%) (Figure 3).

For the permanent zinc phosphate cement, the values were $314.2(61.7) \mathrm{N}$ and $444.8(22.9) \mathrm{N}$, respectively $(\mathrm{P}<0.001)$ (increase of $42 \%$ ) (Figure 4).

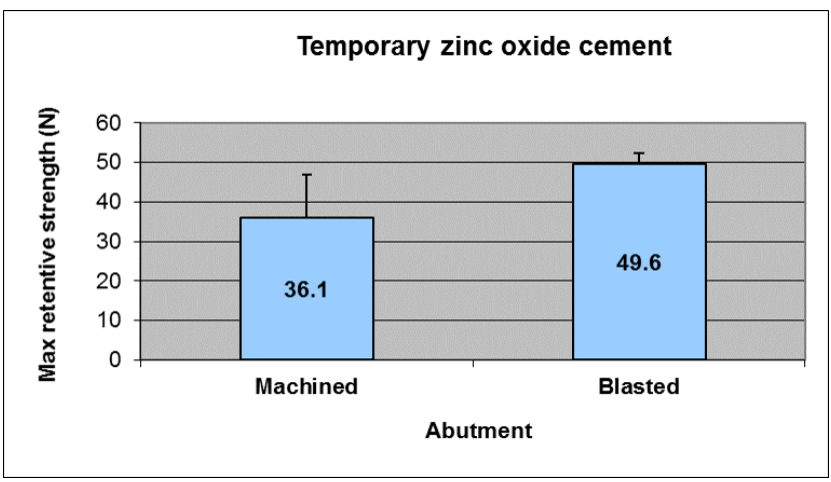

Figure 3. Maximum retention strength $(\mathrm{N})$ of the temporary zinc oxide cement for the original machined and modified (air-blasted with aluminum oxide) abutment surfaces.

Permanent zinc phosphate cement

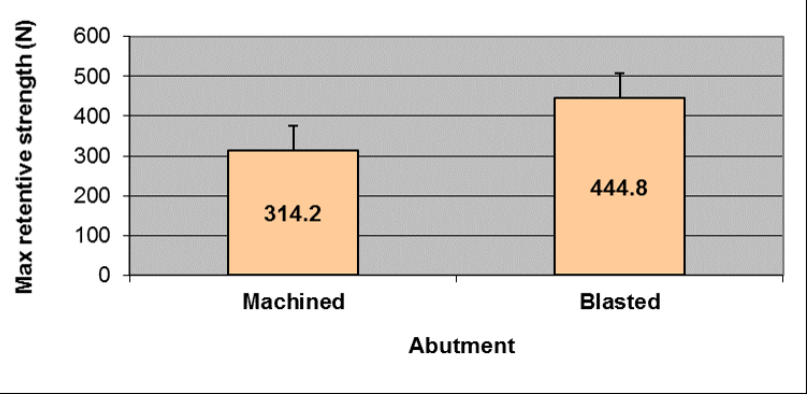

Figure 4. Maximum retention strength $(\mathrm{N})$ of the permanent zinc phosphate cement for the original machined and modified (air-blasted with aluminum oxide) abutment surfaces

\section{DISCUSSION}

This study showed that the treatment of abutment surfaces with aluminum oxide air-blasting increases the retention of cemented metallic restorations with both temporary and permanent cements. Therefore, in challenging clinical cases with little interocclusal space and need for using a short abutment, the modification of original machined surfaces with aluminum oxide blasting significantly improve the retention of cemented metallic restorations with an easy procedure. 
The short wide-platform abutment chosen for this experiment is usually indicated for reduced interocclusal space in the posterior region. The premolar and molar regions are subjected to high masticatory forces during function, which can break the luting agent thin layer and damage the cementation prognosis. This in vitro study allowed the short-term simulation of masticatory occlusal forces, which may affect the strength of the cement retention. This study used a protocol of 5754 cycles with $200 \mathrm{~N}$ load in the fatigue simulation machine, which would be equivalent to seven days of masticatory efforts [12]. This timespan was chosen because it represents the most critical period after the installation of prosthesis, where the cement could suffer the first disruptions in function. Moreover, the provisional cementation is often used for weekly sessions of treatment. Within the experimental conditions of the present study, the zinc phosphate cement showed a maximum retention strength ten times higher than the temporary non-eugenol zinc oxide cement.

There is no consensus on the definition of the frequency of masticatory cycles, because there is great variation between individuals and within same person, also depending on the type of food [13]. Previous studies simulated mechanical fatigue for longer periods and found that the strength retention was significantly altered due to the type of cement, and not to the load cycling. Dudley et al. [13] evaluated the cements Panavia F, Ketac Cem, and Temp Bond NE after 192, 5.000 and 10.000 cycles simulating a week, six months, and one year, respectively. Compared with the control group, the Panavia F showed a significant decline in retention after cycling. For Ketac Cem and Temp Bond $\mathrm{NE}$ the average strength retention was higher in all groups with load cycling, however the average retention for Ketac Cem and Temp Bond NE was not statistically significant for each group with cyclic loading.

Besides the occlusal forces, several environmental factors such as changes in oral temperature and saliva $\mathrm{pH}$ can potentially affect the cement properties and retention, but the results are contradictory in the literature. Garey et al. [14] observed that the contamination by the blood decreases the strength of retention of cemented restorations after thermocycling and mechanical cycling. The authors reported that thermocycling did not significantly reduced the strength of retention of zinc phosphate cement as opposed to cyclic loading, although this decrease in retention was not clinically relevant. Ongthiemsak et al. [15] observed reduction in retention of Temp Bond NE with the increasing number of cycles $(500.000,1.000 .000$ and 5.000 .000 cycles), although not statistically significant compared to the control group.

Different results are derived from both the characteristics of the luting agent and the cemented surface [10]. Kim et al. [6] evaluated four types of cement over abutments with machined, $50-\mu \mathrm{m}$ aluminum oxide blasted, and diamond drill abraded surfaces. They found that the combination of cement type and surface modification influenced the retention. For Temp Bond NE, retention was higher on blasted surface than machined surface, with less restraint to the surface roughness. On the other hand, the retention with zinc phosphate varied with the metal and abutment types (dentin or metal). Interestingly, de Campos et al. [7] report that the retentive strength of the sandblasted and grooved abutments was similar, despite marked differences in surface profiles and roughness parameters.

This in vitro study has some limitations for translation of the findings to the clinical setting. The simulation of mechanical fatigue used a fixed and standard load in the vertical direction of the long axis of the abutment, which do not correspond to the multidimensional fatigue in the mouth during function. Furthermore, this experiment did not simulate other oral and function characteristics, such as saliva and bolus, the specimens were aged in a simulated environment with $100 \%$ humidity at a temperature of $37^{\circ} \mathrm{C}$. The combination of complex forces and other variables probably cause greater stress in the interface between abutment and cement, which is difficult to reproduce in the laboratory. Thus, further studies with more complex simulation models and clinical studies are warranted to clarify the true effect of surface characteristics in the long-term cementation of restorations over different types of abutments.

\section{CONCLUSIONS}

Within the limitations of this study, the findings showed a significant increase of retention with the aluminum oxide blasting of the abutment surface for both temporary zinc oxide and permanent zinc phosphate cements. Therefore, this surface treatment of short and wide abutments may be an easy laboratory or chairside step to improve retention of cast restorations.

\section{ACKNOWLEDGMENTS}

We would like to thank Dr. Luciana Hirakata for her technical assistance. The prosthetic components of the Straumann Dental Implant System were donated by Straumann Brasil Ltda. The laboratory procedures were performed by the laboratory PortoDent, Porto Alegre, Brazil.

\section{REFERENCES}

1. Ramamoorthi M, Narvekar A, Esfandiari S. A meta-analysis of retention systems for implant-supported prostheses in partially edentulous jaws. J Prosthet Dent. 2017;118:587-95. https://doi.org/10.1016/j. prosdent.2016.11.019

2. Shadid R, Sadaqa N. A comparison between screw- and cement-retained implant prostheses. A literature review. J Oral Implantol 2012;38:298-307. https://doi.org/10.1563/AAID-JOI-D-10-00146

3. Bernal G, Okamura M, Muñoz CA. The effects of abutment taper, length and cement type on resistance to dislodgement of cement-retained, implant-supported restorations. J Prosthodont 2003;12:111-5. https:// doi.org/10.1016/S1059-941X(03)00006-8

4. Covey DA, Kent DK, St Germain HA Jr, Koka S. Effects of abutment size and luting cement type on the uniaxial retention force of implant-supported crowns. J Prosthet Dent 2000;83:344-8. https://doi.org/10.1016/S00223913(00)70138-7

5. Bresciano M, Schierano G, Manzella C, Screti A, Bignardi C, Preti G. Retention of luting agents on implant abutments of different height and taper. Clin Oral Impl Res 2005;16:594-8. https://doi.org/10.1111/j.16000501.2005.01159.x 
6. Kim Y, Yamashita J, Shotwell JL, Chong KH, Wang HL. The comparison of provisional luting agents and abutment surface roughness on the retention of provisional implant-supported crowns. J Prosthet Dent 2006;95:450-5. https://doi.org/10.1016/j.prosdent.2006.03.020

7. de Campos TN, Adachi LK, Miashiro K, Yoshida H, Shinkai RS, Neto PT, Frigerio ML. Effect of surface topography of implant abutments on retention of cemented single-tooth crowns. Int J Periodontics Restorative Dent 2010;30:409-13.

8. Michalakis KX, Pissiotis AL, Hirayama H. Cemented failure loads of 4 provisional luting agents used for the cementation of implant-supported fixed partial dentures. Int J Oral Maxillofac Implants 2000;15:545-9.

9. Akça K, Iplikçioğlu H, Cehreli MC. Comparison of uniaxial resistance forces of cements used with implant-supported crowns. Int J Ora Maxillofac Implants 2002;17:524-36.

10. Mansour A, Ercoli C, Graser G, Tallents R, Moss M. Comparative evaluation of casting retention using the ITI solid abutment with six cements. Clin Oral Impl Res 2002;13:343-8. https://doi.org/10.1034/ j.1600-0501.2002.130401.x

11. Kent DK, Koka S, Froeschle ML. Retention of cemented implant-supported restorations. J Prosthodont 1997;6:193-6. https://doi.org/10.1111/j.1532849x.1997.tb00090.x
12. Khraisat A, Stegaroiu R, Nomura S, Miyakawa O. Fatigue resistance of two implant/abutment joint designs. J Prosthet Dent 2002;88:604-10. https:// doi.org/10.1067/mpr.2002.129384

13. Dudley JE, Richards LC, Abbott JR. Retention of cast crown copings cemented to implant abutments. Aust Dent J 2008;53:332-9. https:// doi.org/10.1111/j.1834-7819.2008.00075.x

14. Garey DJ, Tjan AH, James RA, Caputo AA. Effects of thermocycling, load-cycling, and blood contamination on cemented implant abutments, J Prosthet Dent 1994;71:124-32. https://doi.org/10.1016/0022 3913(94)90019-1

15. Ongthiemsak C, Mekayarajjananonth T, Winkler S, Boberick KG The effect of compressive cyclic loading on retention of a temporary cement used with implants. J Oral Implantol 2005;31:115-20. https://doi. org/10.1563/1548-1336(2005)31[115:TEOCCL]2.0.CO;2 